\title{
A Haunted House: Here de Richard McGuire a la luz de la espectralidad derridiana
}

\author{
Breixo Harguindey Barrio
}

Breixo Harguindey Barrio, licenciado en Comunicación Audiovisual (UAB) y máster en Edición (UPF), es investigador independiente experto en historieta. Vinculado a la industria del libro, ejerció como editor en varios sellos.

Fecha de recepción: 19 de agosto de 2017

Fecha de aceptación definitiva: 9 de octubre de 2017 


\title{
Resumen
}

El análisis espectral de Jacques Derrida dota de sentidos a la historieta de vanguardia Here, publicada inicialmente en el magazín $R A W$. El espectro surgiría, precedido por el Ars $M e-$ moriae del mundo clásico, con la cámara oscura moderna que pretende captar la totalidad de la experiencia en una sola habitación, como Here. Al invertirse esta máquina de captura en proyector de espectros, se desata la sospecha contemporánea: el psicoanálisis descodifica la historieta a través de las nociones de cripta y fantasma, mientras la oikonomia marxista desmenuza los collages de McGuire como manifestación fantástico-onírica, a ojos derridianos, por siempre indiscernible.

Palabras clave: historieta, Richard McGuire, espectralidad, Jacques Derrida, hermenéutica de la sospecha.

\begin{abstract}
Jacques Derrida's hauntology gives meanings to the avant-garde comic Here, initially published in $R A W$ magazine. The specter would arise, preceded by the classical Ars Memoriae, within the modern Camera Obscura, intending to capture the whole experience into a single room, such as Here. By inverting this capture machine into a spectral projector, contemporary suspicion is unleashed: Psychoanalysis decodes its intergenerational hieroglyph through the notions of the crypt and the ghost, while Marxist oikonomia cuts up McGuire's collages through spectrality of value and commodity fetishism as a fantasy-dreamlike manifestation, in the eyes of Derrida, forever indiscernible.
\end{abstract}

Keywords: Comics, Richard McGuire, Hauntology, Jacques Derrida, Hermeneutics of Suspicion.

\section{Cita bibliográfica}

Harguindey Barrio, B. «A Haunted House: Here de Richard McGuire a la luz de la espectralidad derridiana», en CuCo, Cuadernos de cómic, n.o 9 (2017), pp. 7-36. 


\section{El magazín de los que han perdido la fe en el nihilismo}

Uno de los buques insignia culturales del Nueva York de los años ochenta fue la revista de cómics dirigida por Art Spiegelman, $R A W$ : «el magazín de aquellos que han perdido la fe en el nihilismo». Durante su primera etapa, esta había adoptado el formato gigante del Interview de Andy Warhol, icono de la posmodernidad en tanto timonel del movimiento pictórico más influido por los cómics, el Pop Art. Por entonces, figuras emergentes del arte callejero y el grafiti, como Basquiat o Keith Haring, eran apadrinados por el de la Factory según salían de la School of Visual Arts donde impartía lecciones, entre otros, el padre espiritual de la revista $M A D$, Harvey Kurtzman. En paralelo a esta mezcla entre alta y baja cultura, artes plásticas y literatura popular, un efervescente panorama musical impregnaba la ciudad desde el noise no-wave de Sonic Youth hasta el explosivo rap de Public Enemy.

En 1989, el primer número de la segunda etapa de $R A W$, ya como libro en tapa blanda, publicaría «Here», una breve historieta de vanguardia firmada por uno de los miembros de esa escena musical, Richard McGuire, bajista del grupo Liquid Liquid. Tras mudarse a un nuevo piso, McGuire se preguntó a sí mismo cómo había sido la vida de los anteriores inquilinos e, influido por el interfaz visual del reciente sistema operativo Windows, dio con una solución revolucionaria para plasmar esta idea en seis páginas de seis viñetas cada una. Tal como en el cine primitivo antes de la irrupción del montaje, todas ellas representan un mismo escenario desde una sola perspectiva fija. Sin embargo, algo excepcional sucede no tanto entre las viñetas, sino, dentro de ellas: una serie de pequeños encuadres se superponen a la vista principal de la habitación mostrando diferentes momentos de la misma, desde la prehistoria al futuro, fechados mediante cartuchos (FIG.1).

El circuito de críticos del noveno arte acogió exultante esta imaginativa solución encontrando justos antecedentes en el «Nervous Rex» de Art Spiegelman, publicado con anterioridad en $R A W$; la magnífica Una Historia de América de Robert Crumb; e, incluso, la serie de tiras de Gasoline Alley, donde se presenta la construcción de una casa. En lo que nadie, ni el propio autor, reparó fue en su llamativa coincidencia con un proyecto de 1986 del arquitecto deconstructivista Peter Eisenman para el Museo de Arte de la Universidad de California en Long Beach, así descrito por él mismo:

La idea era imaginar el solar en el año 2049, cien años después de la fundación de la universidad, y doscientos años después de la época de la fiebre del oro. El edificio toma su forma a partir de un registro que superpone varios mapas: del rancho que existió una vez en el solar, el solar del campus, y de las configuraciones cambiantes de la falla del terreno, un río, un canal y la costa. Se combinan de tal modo que ninguna de las notaciones tiene precedencia sobre ninguna de las otras y que se textualizan las superposiciones coincidentes que hacen las interpretaciones subjetivas. Estas «superposiciones» revelan unas relaciones analógicas que antes estaban obscurecidas cuando se les concedía mayor importancia a algunas notaciones, como los esbozos sociales. Por ejemplo, la relación del canal en el borde norte del solar del museo es similar a la relación del río con todo el solar del campus. Así, podía verse el edificio como un artefacto arqueológico, un palimpsesto de su formación e «historias» superpuestas. ${ }^{1}$

${ }^{1}$ Eisenman, P. Recent Projects. Nijmegen, Idea Books, 1989, p. 25. Cit. en Jameson, F. Las semillas del tiempo. Madrid, Trotta, 2000, p. 147. 

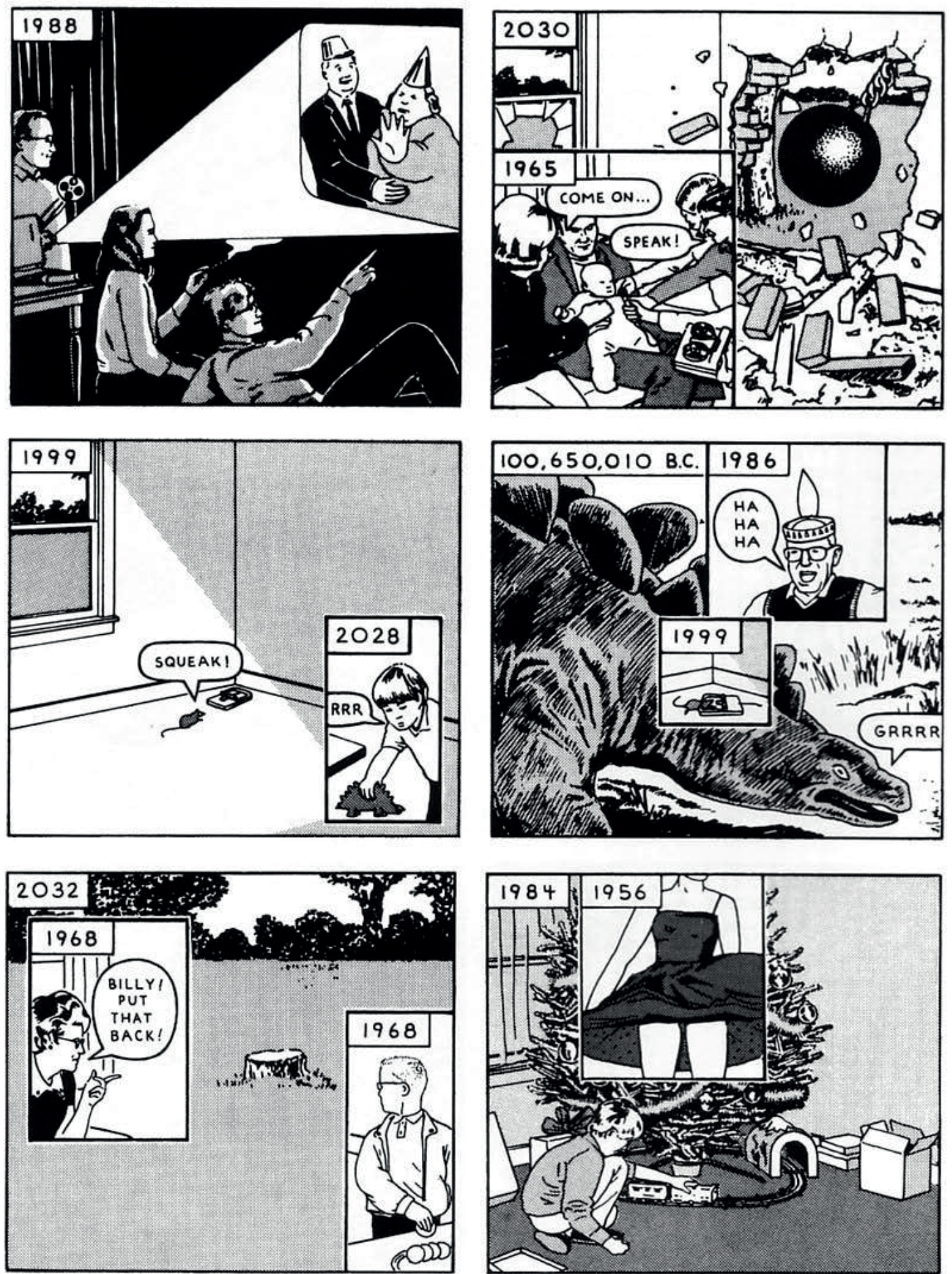

FIG. 1.McGuire. R. «Here», en $R A W$, vol. 2, n.o 1

(1989), p. 72. 
Esta curiosa afinidad de propósitos entre el cómic de McGuire y el edificio de Eisenman tuvo que esperar unos años para cobrar sentido a través del filósofo cabecera del segundo, Jacques Derrida, quien en su Espectros de Marx (1993) alumbró la teoría contemporánea de la espectralidad (hauntology). Igual que había sucedido con el término deconstrucción, la hauntology se popularizó hasta lo banal para extender su aplicación a disciplinas como el cine, la fotografía, los videojuegos y, en primer lugar, especialmente, la música.

En la primera década del siglo xxi, diferentes críticos comenzaron a aplicar esta etiqueta en sus blogs para identificar a un segmento difuso del pop y, especialmente, la electrónica a partir de artistas como Burial, Oneothrix Point Never, Mordant Music, William Basinski, The Caretaker o, incluso, Ariel Pink Haunted Graffiti. Los libros Retromania (2011) de Simon Reynolds y Ghosts of My Life (2014) de Mark Fisher darían cuerpo a la hermenéutica de este movimiento como expresión de lo espectral a través del ruido de fondo que evidencia los soportes materiales - susurro y saltos de aguja en el vinilo, reverberaciones $d u b$ del casete...- - y de la reapropiación de muestras musicales o samplers esotéricos — bandas sonoras de películas de serie $B$, antiguas emisiones radiofónicas...-A poco que profundizara en la tesis derridiana, Richard McGuire, él mismo músico, debió percatarse por entonces de que «Here» había sido, sin lugar a dudas, precursora inconsciente en la historieta de esa bauntology que inundaba las publicaciones para melómanos savants.

\section{Los lugares y las imágenes}

Así como, a menudo, se menciona al tren o ferrocarril como figura alegórica del mecanismo del cine, la secuencia de viñetas in praesentia típica de la historieta ha sido comúnmente equiparada a la sección vertical de un bloque de viviendas o edificio, una imagen recurrente en el noveno arte, de Will Eisner a Chris Ware pasando por nuestra entrañable «13, Rue del Percebe».

Como la propia secuencia de imágenes discretas, este símil entre habitación y viñeta proviene del mundo clásico europeo, helénico en el primer caso, ${ }^{2}$ romano en el segundo. Esta técnica, asociada al Ars Memoriae, se describe por primera vez durante el año 90 a. C. en la Retórica a Hernenio:

La memoria artificial está formada por entornos [loci] e imágenes. Llamamos entornos a ámbitos determinados por la naturaleza o por la mano del hombre [...] Por ejemplo, una casa, un intercolumnio, una habitación, una bóveda o cualquier cosa parecida. Las imágenes son formas, símbolos, representaciones de aquello que queremos recordar. [...] Los entornos son como las tablillas de

\footnotetext{
${ }^{2}$ Weitzman, K. El rollo y el códice: un estudio del método y origen de la iluminación de textos. Donostia, Nerea, 1990, p. 23: «En el periodo helenístico se inventó un nuevo método. [...] Al concebir cada una de las situaciones del texto como una imagen en sí misma, el artista crea series de composiciones consecutivas, pero con acciones centradas e independientes, repitiendo los actores en cada una de ella, y así guardando al mismo tiempo las reglas de la unidad de tiempo y lugar. [...] De la misma manera que el ojo cuando lee un texto escrito va de un renglón a otro, así va ahora de una imagen a la siguiente, por así decirlo, leyéndola, y el espectador visualiza en su mente los cambios que ocurren entre las diversas escenas».
} 
cera o los papiros, las imágenes son como las letras, la disposición y localización de las imágenes es como la escritura. ${ }^{3}$

A estas relaciones cruzadas entre imagen, artificio, escritura y memoria, persistentes en Grecia y Roma al menos desde el Fedro, cabe añadir una más a partir de la leyenda originaria del Ars Memoriae que, años después, relataría Cicerón en Sobre el Orador:

Estando Simónides cenando en Cranón, lugar de Tesalia [...] se le anunció [...] que saliese afuera [...] y que mientras tanto, el comedor donde Escopas celebraba el banquete, se había desplomado, que el propio Escopas con sus allegados había muerto sepultado por los escombros; y que cuando los suyos quisieron enterrarlos y no poder en modo alguno reconocerlos, aplastados como estaban, se dice que Simónides había identificado a cada uno de los que había que enterrar por acordarse en qué lugar estaba recostado cada cual. ${ }^{4}$

De tal manera, Simónides reconstruye en su memoria el edificio ahora derrumbado y, en cierto modo, resucita al mismo tiempo a aquellos comensales, vinculando la imagen de cada muerto al espacio que en él le correspondía. El perjurio de Escopas, que incumple su promesa de honorarios a Simónides, habría causado el desplome de su residencia, pero la facultad forense de este último la restituye y, con ella, la fiabilidad del lenguaje, eso sí, como escritura de imágenes post mortem.

Aparentemente las viñetas de «Here» participan de este vínculo entre el lugar y la memoria a través de una habitación, pero cometeríamos un error si considerásemos a McGuire como reencarnación de Simónides ya que su estrategia impugna de manera radical el Ars Memoriae en tanto fundamento de otra metáfora muy extendida sobre el noveno arte: la del mapa temporal. El mapa es la escritura cardinal de los pueblos nómadas, así el ojo lector recorre la superficie de una página señalizada con diferentes objetos tal como una horda se despliega sobre el tablero de su territorio, un movimiento que convierte el plano espacial en extensión temporal. Popularizado por McCloud, este mecanismo de flujos oculares se explicita y pone en juego a través de ejercicios vanguardistas basados en diagramas que multiplican los vectores de lectura, ejemplarmente en Chris Ware (FIG. 2).

Sin embargo, en Here las viñetas no se yuxtaponen simplemente una al lado de la otra, sino que se superponen unas sobre otras — un problema irresoluble para las teorías que trasladan los modelos lingüísticos al análisis del cómic—. ${ }^{5}$ Este fenómeno de la superposición

\footnotetext{
3 Anónimo. Retórica a Herenio. Madrid, Gredos, 1997, pp. 199-200.

${ }^{4}$ Cicerón, M. T. Sobre el Orador. Madrid, Gredos, 2002, pp. 362-363.

5 Tal es el caso de la semiótica continental representada por Groensteen, T. Système de la Bande Desinée. París, Presses Universitaires de France, 1999, pp. 100-106, que analiza la incrustation como fenómeno por el cual la simultaneidad de la pintura irrumpe en el (normal) desarrollo secuencial del relato. La gramática generativa angloamericana de CoHn, N. Visual Syntactic Structures: Towards a Generative Grammar of Visual Language. 2003. Disponible en http://visuallanguagelab.com/P/VSS1.pdf si bien reconoce que el overlay cuestiona la lógica del mapa temporal y la elipsis narrativa, es incapaz de articular un análisis verosímil del mismo a partir de su concepción descarnada, puramente cognitiva, de las viñetas. En justicia, el primero de-
} 


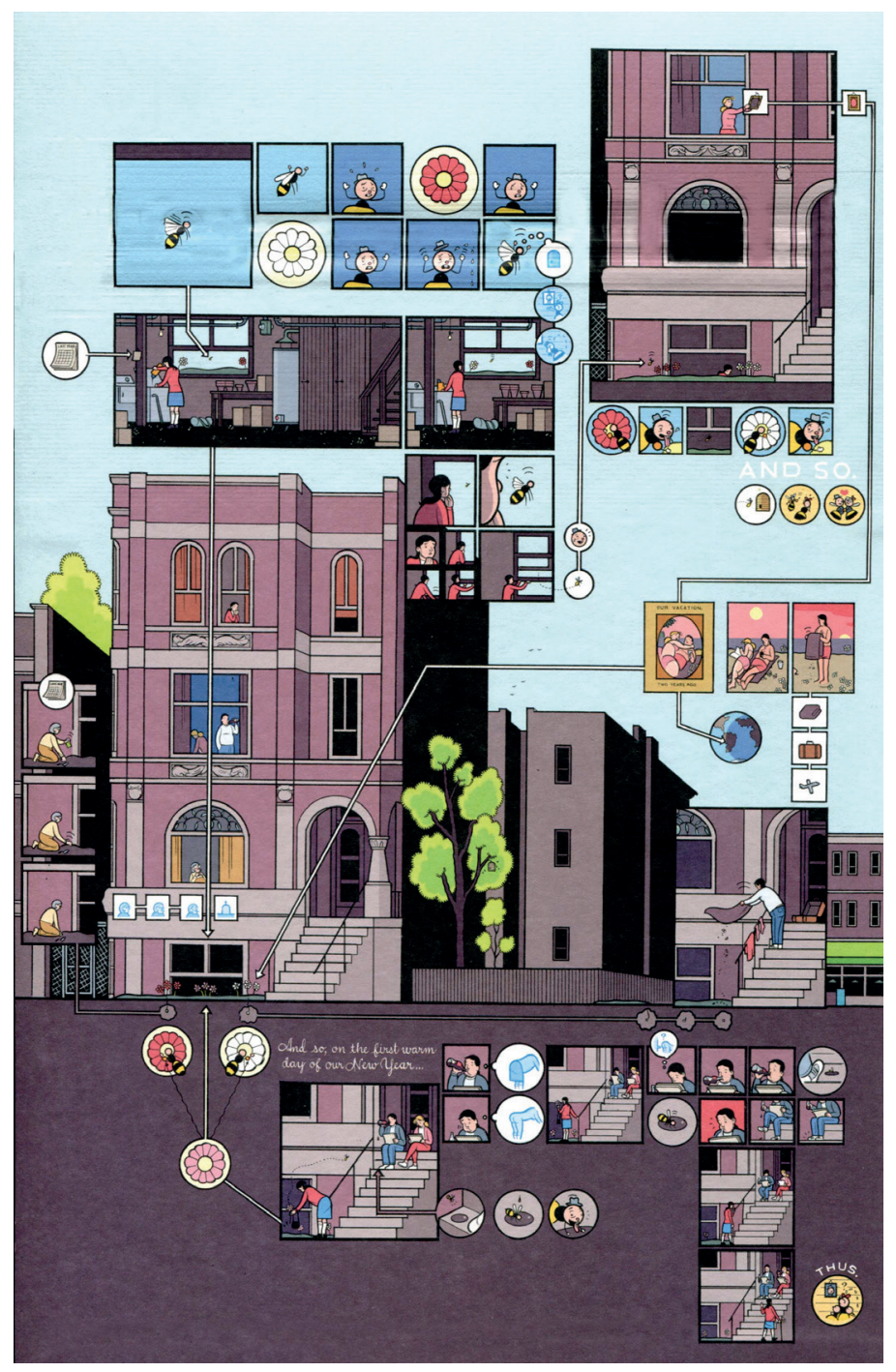

FIG. 2. Ware, C. «Building Stories», en Acme Novelty Library, n. ${ }^{\circ} 16$ (2012).

es habitual en la historieta y mucho menos extravagante que la propuesta experimental de McGuire. Allende la superficie de una página, las hojas de cualquier libro en papel se interponen entre sí y somos nosotros, los lectores, quienes activamos físicamente su engranaje a través de nuestras manos. Este eje de la profundidad es un lugar privilegiado de interacción

dicó un ensayo a la versión original de Here, v. Groensteen, T. «Les lieux superposés de Richard McGuire», en Urgences, n. 32 (1991), pp. 95-103. Disponible en http://www.erudit.org/fr/revues/urces/1991-n32-urces651/025651ar.pdf que completaría en Groensteen, T. «Richard McGuirre: Ici», en Musée de la Bande Dessinée (Angulema, marzo de 2016). Disponible en https:/www.editionsdelan2.com/groensteen/spip. php?article60. Ambos textos vinculan este tebeo con su noción de tressage [trenzado] que supone que «toda viñeta está potencial sino efectivamente, en relación con todas las demás. Esta totalidad [...] responde así a un modelo de organización que no es aquel, lineal, de la tira o la cadena, sino aquel, explosivo, de la red». Groensteen (1999), p. 173. 


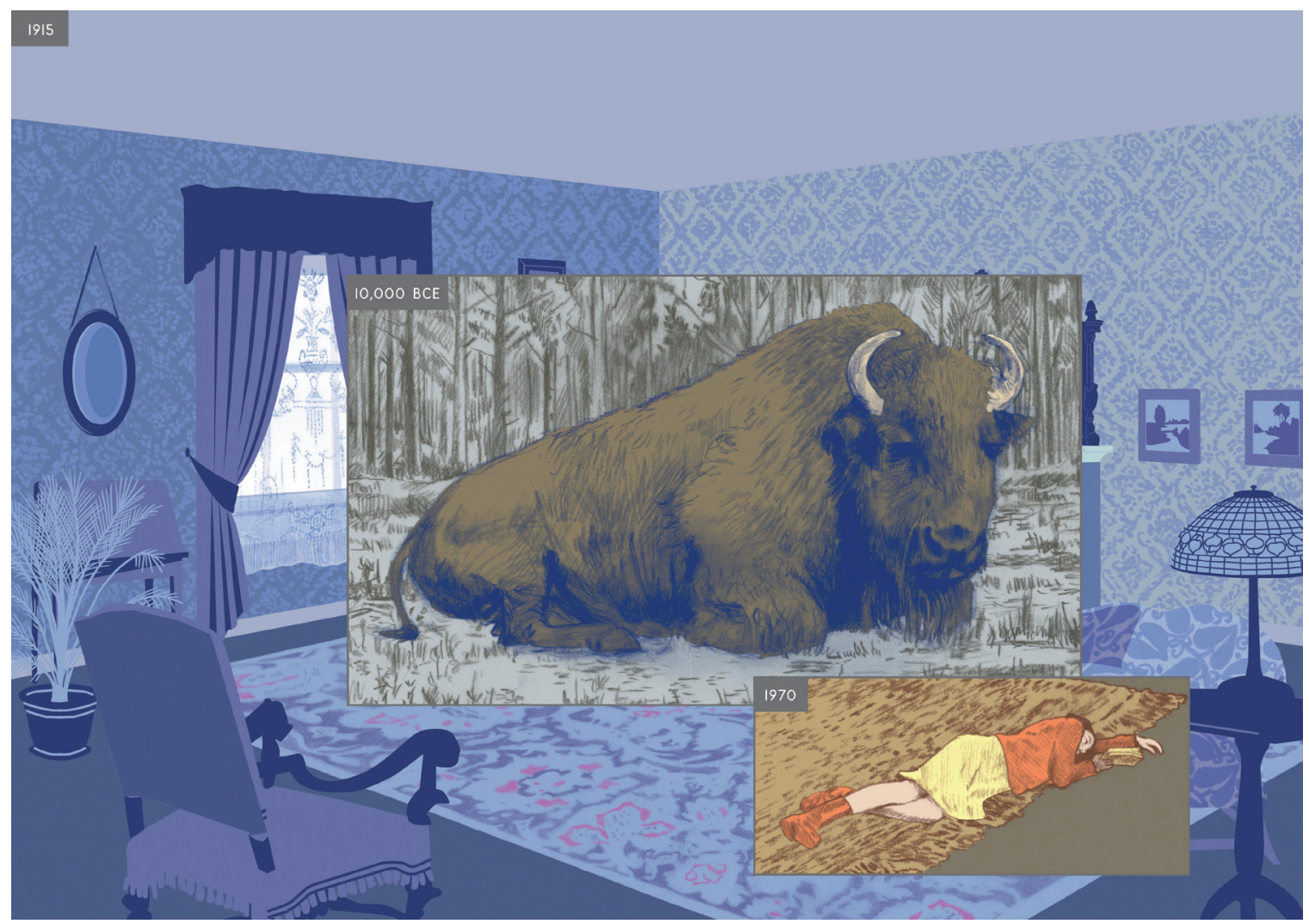

FIG. 3. McGuire, R. Here. Londres, Hamish Hamilton, 2014, pp. 221-222.

entre el lector y la obra - en general, presupuesto irreflexivamente como natural e implícito a la lectura- De esta manera, pasamos del espacio plano de la página al volumétrico del códice abriendo así, literalmente, una nueva dimensión para el noveno arte enlazada con los soportes materiales en que se nos presenta. ${ }^{6} \mathrm{Si}$ los diagramas de Chris Ware visualizan el recorrido del ojo por la página, los ciclos de viñetas superpuestas en Here animan el ejercicio de las manos sobre el libro.

En verdad, el término superposición no hace justicia a la obra de McGuire ya que su concreción vuelve absurdas las dicotomías entre fondo y figura o interior y exterior, esta última aquí de gran importancia. Cuando, por ejemplo, la viñeta de un bisonte del 10000 a. C. se superpone a otra toma de una semipública sala de estar en 1915 (FIG. 3), ¿̇acaso no estamos como viendo a través de una ventana o agujero espaciotemporal? La reformulación del Ars Memoriae en Here, su relación entre lugares e imágenes, se inspira precisamente en un sistema operativo que funciona a través de ventanas, Windows, un sistema de archivos:

${ }_{6}^{6}$ Para una introducción al funcionamiento de esta tercera dimensión en relación con los dispositivos del cómic v. Harguindey Barrio, B. «The Order of Comics: Dynamics of Ninth's Art Devices» en Cañero, J. y Claudio, E. (eds.) On the Edge of the Panel: Essays on Comics Criticism. Newcastle upon Tyne, Cambridge Scholars Publishing, 2015, pp. 65-73. 
El sentido de «archivo», su solo sentido, le viene del arkheîon griego: en primer lugar, una casa, un domicilio, una dirección, la residencia de los magistrados superiores, los arcontes, los que mandaban. [...] Habida cuenta de su autoridad públicamente así reconocida, es en su casa entonces [...] donde se depositan los documentos oficiales. Los arcontes son ante todo sus guardianes. No solo aseguran la seguridad física del depósito y del soporte, sino que también se les concede el derecho y la competencia hermenéuticos. Tienen el poder de interpretar los archivos. [...] Así es como los archivos tienen lugar: en esta domiciliación, en esta asignación de residencia. La residencia, el lugar donde residen de modo permanente, marca el paso institucional de lo privado a lo público, lo que no siempre quiere decir de lo secreto a lo no-secreto. ${ }^{7}$

\section{La cámara y el espectro}

El vínculo entre Here y su soporte físico se observa mejor en la versión de 2014 en forma de libro que introduce, además de su amplitud, dos novedades respecto a la historieta publicada en $R A W$. La primera es el color, cuyo uso McGuire ya había explorado en una revisión para la revista alemana Strapazin (FIG. 4). En segundo lugar, mientras en el original nos encontrábamos ante una rejilla de viñetas, en la edición de Pantheon/Penguin cada doble página muestra una sola vista desde una perspectiva fija. ${ }^{8}$ Frente a la retícula en blanco y negro, esta combinación del afloramiento cromático junto al ángulo visual único de la habitación remite a una tecnología — obviada por Jacques Derrida - que iba a incorporar el término espectro a nuestro léxico cotidiano: la cámara oscura. ${ }^{9}$

Si bien el mecanismo de la cámara oscura se conoce desde la antigüedad, sería a partir del siglo XVII cuando este aparato óptico llegó a identificarse con el funcionamiento de la mente humana a partir de la revolución del sujeto en la filosofía moderna, cuya mejor ilustración correría a cargo del empirista británico John Locke:

7 Derrida, J. Mal de archivo. Madrid, Trotta, 1997, p. 10. Un comentario muy agudo sobre esta obra se ofrece en Groys, B. Bajo sospecha: una fenomenología de los medios. Valencia, Pre-textos, 2008, pp. 236-237: «Constata Derrida que el archivo está infectado de una enfermedad archivistica incurable, que consiste en que el archivo solo puede disponer de un tiempo finito [...] Y esta escasez de tiempo de los archivos bloquea el paso del contemplador al interior del archivo. Todos los signos del archivo [...] se convierten en espectros [...] pues el espectro no es otra cosa más que el significante después de la muerte del significado [...] Como Derrida solo concibe la sujeción de los significantes como una sujeción ideal a su significación - y no como una sujeción mediática y material en algún lugar de la superficie mediática - puede describir los signos del archivo como signos que deambulan libremente. Pero claro: el archivo también es, sobre todo, un lugar determinado. Es una memoria que retiene los signos también materialmente cuando se han librado de toda significación». Para una excelente y pormenorizada deconstrucción de las relaciones entre Here y los interfaces gráficos de usuario (GUI) v. Konstantinuo, L. «A Theory of Here», en The Account n. ${ }^{\circ}$ (2015). Disponible en http://theaccountmagazine.com/?article=a-theory-of-here.

${ }^{8}$ A estas diferentes entregas de Here hay que añadir un par de tiras que se publicaron antes de la historieta de $R A W$ en la revista Bad Nerws de Mark Newgarden y Paul Karasik, y dos adaptaciones: Masick, T. y Trainor, B. Here. [Video]. Nueva York, Rochester Institute of Technology, 1991. Disponible en https://www.youtube. com/watch?v=57hR44mB5u0 e, inmediatamente después del libro, una aplicación para la tableta digital Ipad que permitía combinar aleatoriamente las viñetas, reforzando así su lógica de archivo no-lineal.

${ }^{9}$ Entre las pinturas que a lo largo del tiempo adornan este cuarto de estar se repite el motivo de la mujer que lee - así La lectora de Fragonard o Mujer leyendo una carta y Muchacha leyendo una carta de Vermeer- mostrando una predilección por este último artista flamenco célebre por su empleo del mismo instrumento. 


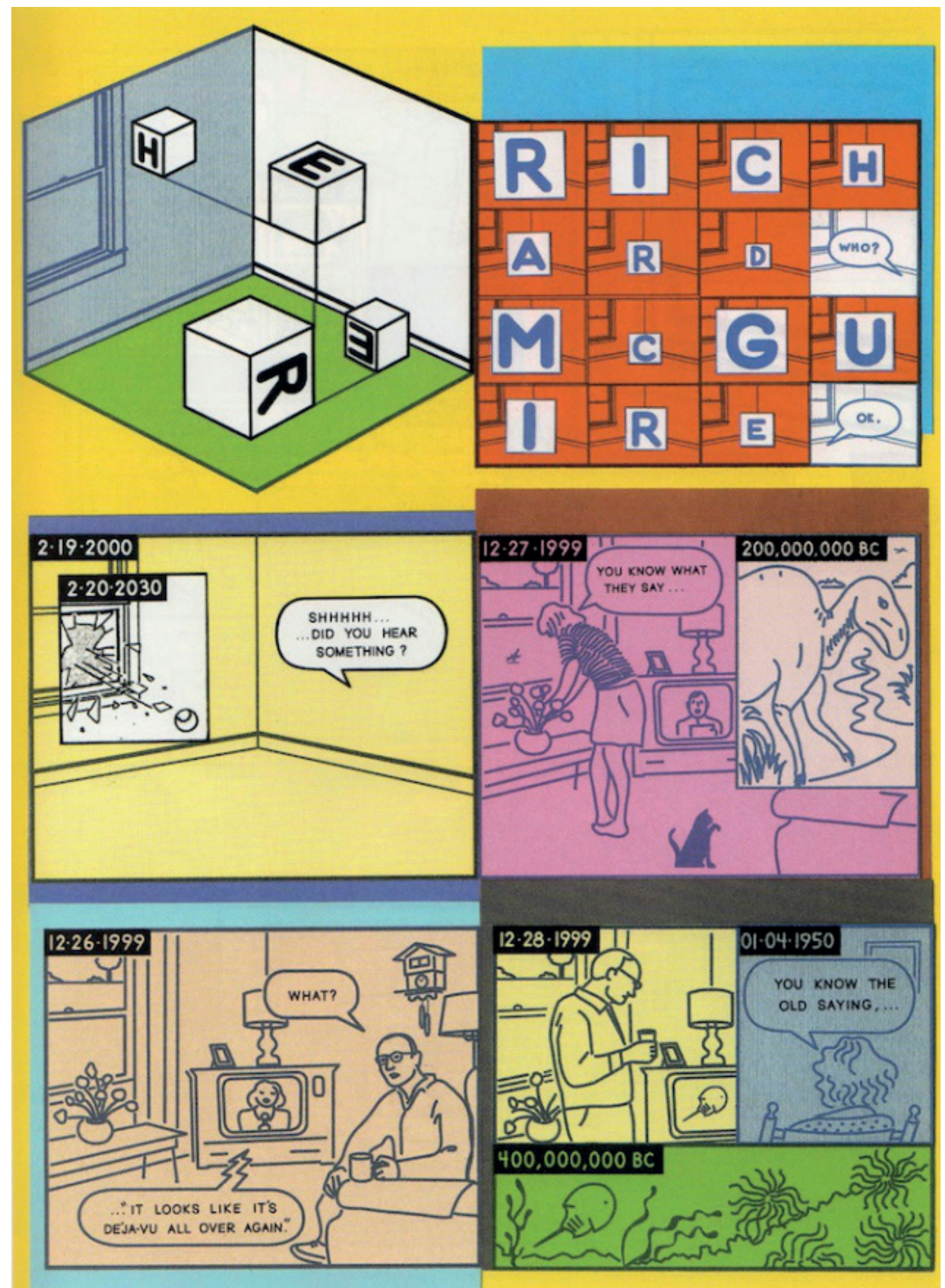

FIG. 4. McGuire, R. «Here», en Strapazin, n. ${ }^{\circ}$ 59 (2000). 
El entendimiento no es muy diferente a una cabina totalmente cerrada a la luz, con una sola y pequeña apertura para dejar entrar las semejanzas visibles externas, o ideas de las cosas exteriores; si las imágenes que entrasen en esta cámara oscura [dark room] se quedaran allí y permanecieran en orden como para ser encontradas cuando la ocasión lo requiera, se asemejaría mucho el entendimiento del hombre en relación con todos los objetos de la vista y a las ideas de ellos. ${ }^{10}$

Este proceso ideológico sería ejemplarmente desmenuzado en años recientes por Jonathan Crary, quien con certeza apunta:

La cámara oscura realiza una operación de individuación: en el interior de sus oscuros confines, define al observador necesariamente por su aislamiento, reclusión y autonomía. Impulsa una suerte de ascesis o retirada del mundo, con el fin de regular y purificar la relación de uno con los múltiples contenidos del, ahora, mundo «exterior». Así, la cámara oscura es inseparable de cierta metafísica de la interioridad. ${ }^{11}$

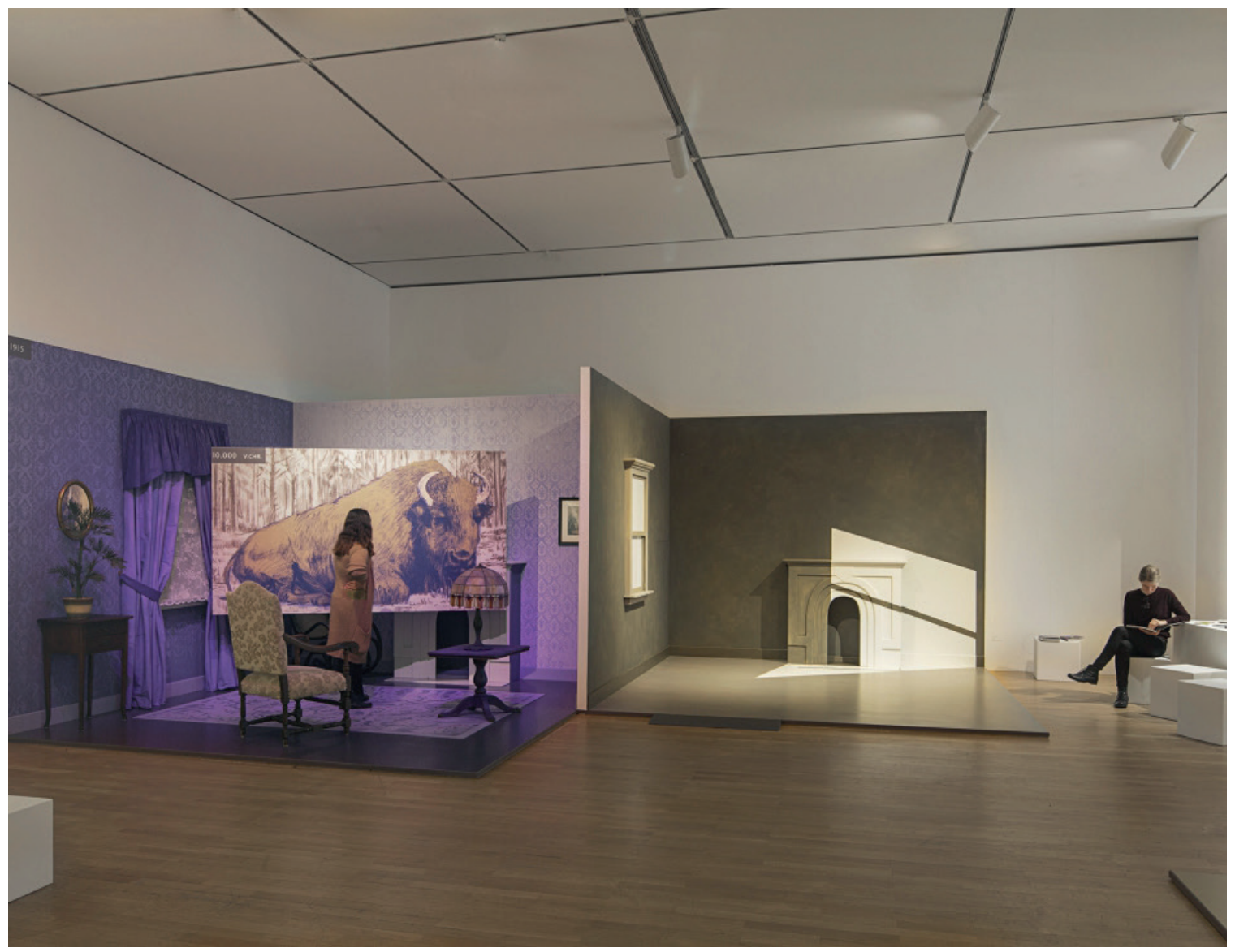

FIG. 5. Instalación TimeSpace: After «Here» en el Museum Angewandte Kunst de Frankfurt (2016).

${ }^{10}$ Locke, J. Ensayo sobre el entendimiento humano Lib. II, Cap. XI, 17. Londres, Thomas Teck, 1825, p. 95. [Mi traducción]. Disponible en https://archive.org/stream/humanunderstandi00lockuoft\#page/n117/mode/2up.

11 Crary, J. Las técnicas del observador. Murcia, CENDEAC, 2008, p. 63. 
En cierto modo, el cuarto poblado por espectros de Here reproduce la perspectiva fija y omnisciente de esa mente ante la que se despliegan los acontecimientos en una cámara oscura, pero, de nuevo, corporeizada en forma de libro al hacer coincidir la esquina de la habitación con la intersección que corta cada doble página, como se aprecia explícitamente en el montaje tridimensional para su exposición en el Museo de Artes Aplicadas de Frankfurt (FIG. 5). ${ }^{12}$

En oposición a las teorías evolucionistas sobre este instrumento como punto de inflexión del arte figurativo - popularizadas, entre otros, por el pintor David Hockney - ${ }^{13}$ Crary insiste en su carácter gnoseológico y científico cuya aplicación emblemática sería la Óptica de Isaac Newton:

En una estancia muy oscura [dark chamber] en un agujero redondo de aproximadamente una tercera parte de una pulgada de anchura practicado en el postigo de una ventana, coloqué un prisma de vidrio, a través del cual el rayo de la luz del sol, que entraba por aquel agujero, podía ser refractado hacia arriba en dirección al muro opuesto de la cámara y, allí, formar una imagen coloreada del sol. ${ }^{14}$

Newton daría el nombre de Spectrum a esta imagen solar, aunque a su juicio no procedía finalmente de nuestra estrella sino de Dios, como muestra el pacto del Génesis con Noé a través del arcoíris. Con el espectro cromático surgiría la teoría del color moderna, un siglo después contestada por Goethe arguyendo que - antes que físico o químico- este es un fenómeno fisiológico y psicológico. ${ }^{15}$ En cualquier caso, el análisis espectral iba a hacer fortuna para extenderse hoy entre campos tan diversos del saber como la espectroscopia astrofísica o el espectrograma acústico.

La tesis de Crary se revuelve contra el presupuesto de una evolución determinista que sitúa a la cámara oscura como precursora del cine y la fotografía ya que, a partir del siglo XIx, la relación entre la mente y los espectros se reenfocaría desde la hermeneútica de la sospecha en términos de inversión, ocultamiento y mistificación de la realidad. ${ }^{16}$ Así Marx proclama que «en toda la ideología los hombres y sus relaciones aparecen invertidos como en una cámara oscura $»^{17}$ o como antes escribía Nietzsche: «iMundo de fantasmas en el que vivimos!

${ }^{12}$ McGuire tomó esta estrategia de un grabado de Shunga, o arte erótico japonés, lo que da pie quizás a pensar en nuestra primera habitación íntima, la placenta. Esta, como otras fuentes documentales de Here, provenían del fondo de la Morgan Library de Nueva York que — dos años antes de la exposición de Frankfurtle había dedicado una primera muestra, From Here to Here: Richard McGuire Makes a Book.

13 Hockney, D. El conocimiento secreto. Barcelona, Destino, 2001. Disponible en forma de documental audiovisual en https://www.youtube.com/watch?v=oqDwBXG_EdU.

${ }^{14}$ Newton, I. Óptica, 1704. Cit. en Crary. Op. cit., p. 65.

${ }^{15}$ La secuencia central de dobles páginas con amaneceres y puestas de sol en Here quizás señale una analogía con ese medio turbio que el literato alemán — quien había trabajado como meteorólogo— consideraba como un fenómeno primordial.

16 Ricoeur, P. Freud: una interpretación de la cultura. México, Siglo XXI, 1990, pp. 32-35.

${ }_{17}$ Marx, K. La ideología alemana. Barcelona, Ediciones Grijalbo, 1974, p. 26. 
¡Mundo torcido, al revés! Vacío, y, sin embargo, soñado pleno y recto», ${ }^{18}$ una tradición en la que se inscribe la obra de Jacques Derrida:

Todos los desarrollos modernos de la tecnología y la telecomunicación en lugar de restringir el espacio de los fantasmas como podríamos pensar, que la ciencia o bien la técnica deja atrás la época de los fantasmas, de las casas solariegas, de una cierta tecnologia, de una cierta época perinatal... pienso, al contrario, que el futuro es de los fantasmas y que la tecnología moderna de la imagen, de la cinematografía, de la telecomunicación desata el poder de los fantasmas, el retorno de los fantasmas. ${ }^{19}$

Nueve años después de la Revolución francesa Étienne Gaspar Robert ya había materializado estas conceptualizaciones avanzadas durante el barroco por Athanasius Kircher, quien anotaba que los principios ópticos de la cámara oscura eran reversibles a través de un proyector de imágenes que acabaría por conocerse como linterna mágica o fantasmagoría. El mecanismo de la cámara, antes identificada con el ojo de la mente, proyectaba ahora sus propias ilusiones espectrales, reveladas así como artificios humanos.

Diferentes episodios sobre las técnicas de representación visual se esparcen a lo largo del volumen de Here: el cortejo campestre de un pintor de paisajes en $1870 ;{ }^{20}$ la serie de fotos de familia que retratan el paso de los años; las videoproyecciones caseras que ya se encontraban en su entrega de $R A W$; varias emisiones televisivas y radiofónicas. El más significativo, con todo, se da en el futuro, concretamente en el año 2213, cuando una suerte de guía turística espaciotemporal explica a sus espectadores: «a través de nuestro programa de reconstrucción y visualización, hemos podido acceder a un hogar construido en el siglo xx que una vez estuvo en este lugar» (FIG. 6).

Entre los múltiples presagios apocalípticos de Here para el futuro de la humanidad —inundaciones, radioactividad, colapso y expansión del sol...- este contrasta por su esperanza en una exhumación virtual de los espectros que, de esta manera, haga justicia - aun en forma de archivo - a la pérdida en el olvido de nuestros signos de identidad — reloj, cartera, llaves...-, a nuestra muerte inexorable, proyectándonos hacia un porvenir en la matriz de una fantasmagoría, ${ }^{21}$ como elucubra Pedro Moura:

18 Nietzsche, F. Aurora. Libro II, aforismo 118, Barcelona, Alba Editorial, 1999, p. 118.

19 Declaraciones de Jacques Derrida en el documental Ghost Dance (1983), de Ken McMullen. Disponible en https://www.youtube.com/watch?v=0nmu3uwqzbI

${ }^{20}$ Este no es otro sino George Innes, de New Jersey, en cuyas obras se inspiran las ya mencionadas secuencias de amaneceres y ocasos centrales del libro.

${ }^{21}$ Este futuro hipotético podría descifrar aquello que Derrida denomina lo mesiánico sin mesianismo: «Ya sea la promesa de esto o aquello, ya sea, o no, cumplida o ya resulte imposible de cumplir, necesariamente hay promesa y, por tanto historicidad como porvenir». DeRrida, J. Espectros de Marx: el Estado de la deuda, el trabajo del duelo y la nueva Internacional. Madrid, Trotta, 2012, p. 88. El principal filósofo francés del realismo especulativo plantea una teoría muy semejante: frente a la espectralidad como duelo insuperable existe la posibilidad de una resurrección de los muertos a través de la futura aparición de un Dios que actualmente no existe, v. Meillansoux, Q. «Spectral Dilemma», en Collapse, vol. 5 (2008), pp. 261-276. Igualmente, en 
Podríamos argumentar, quizás, que McGuire subsume toda la estructura de Here bajo esta potencialidad narrativa de ciencia ficción, como si nosotros, los lectores, estuviésemos actualmente observando la navegación temporal posibilitada por este brillante y futuro mecanismo tecno-lógico. ${ }^{22}$

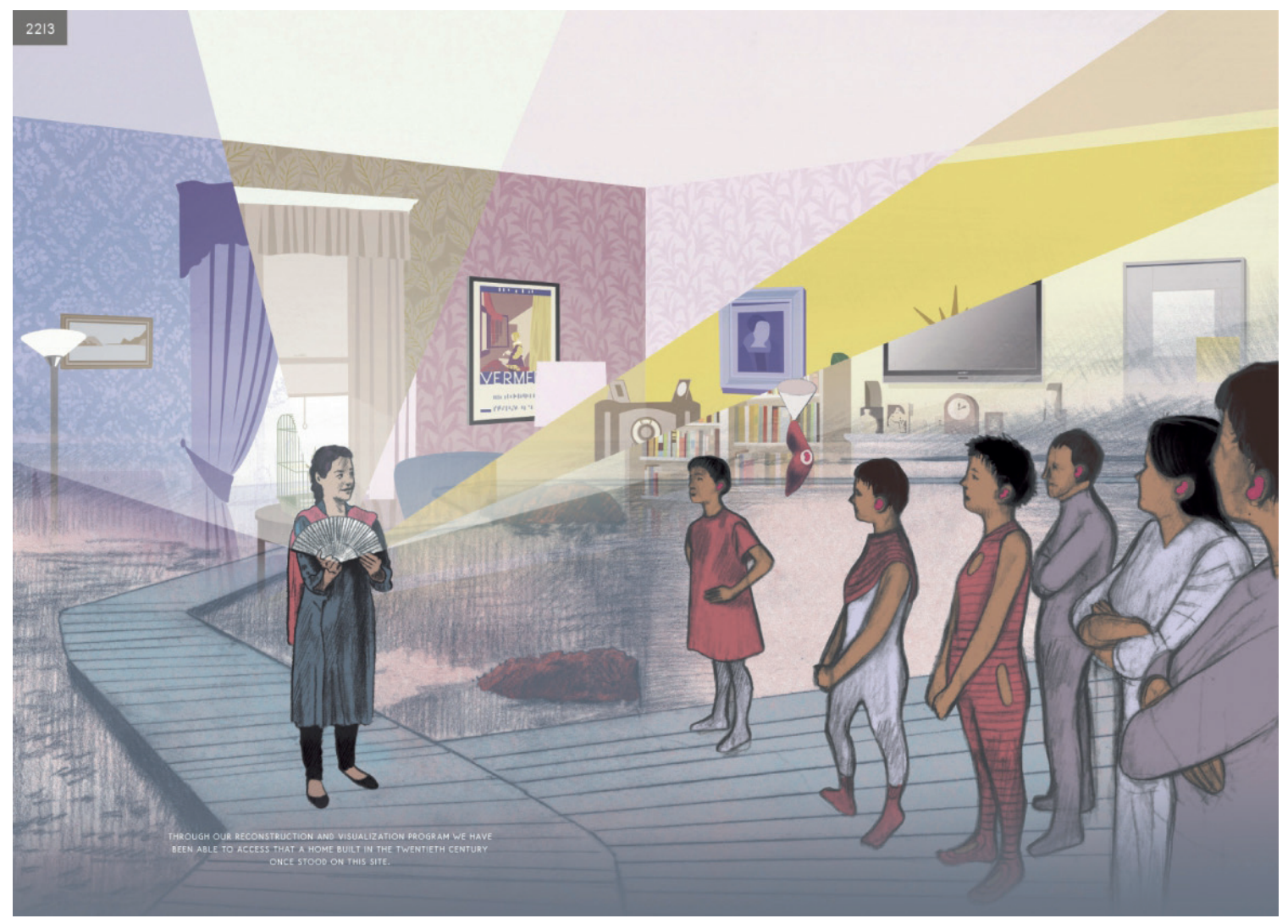

FIG. 6. McGuire, R. (2014). Op. cit., pp. 255256.

Porvenir ilusorio, en cualquier caso, ya que esta fantasmagoría resucita tan solo un domicilio desprovisto de sus antiguos habitantes, tal como refleja otra obra de vanguardia, SPUK de Niklaus Rüegg, cuyas páginas — tomadas de los tebeos del Pato Donald - al eliminar a sus protagonistas nos proveen de una cámara, si cabe más siniestra, vacía de sus espectros (FIG.7).

Esa voluntad de hacer de todos los tiempos algo simultáneo o, incluso paradójicamente, contemporáneos también se manifiesta en las curiosas simetrías entre el comienzo y la parte final de Here. La portada muestra el exterior de una ventana - presumiblemente de la habitación - mientras su contraportada nos enfrenta a un muro trasero, como si el mismo libro contuviese en sí la vivienda. Casi de inmediato, en la página de créditos inicial, observamos

el documental Trascendent Man (2009) el mesías poshumanista Ray Kurtzweill atribuye esta función a la singularidad tecnológica que podría revivir a los muertos bajo forma de Inteligencias Artificiales.

${ }^{22}$ De Moura, P. «Time is a Memory, Liquid is a Cup», en Du9: l'autre bande dessinée, 2015. Disponible en http://www.du9.org/en/dossier/time-is-a-liquid-memory-is-a-cup/ 



FIG. 7. RÜEGG, N. SPUK. Zurich, Edition Fink, 2004.

una doble estantería medio llena frente a una caja vacía, mientras en la última página, con las dedicatorias, se ve la misma estantería vacía frente a una caja cerrada. En la primera aparición humana del cómic, una señora se pregunta en medio del cuarto: «¿Por qué he venido aqui otra vez?». Cuestión que encuentra respuesta al cierre del volumen: «Ahora lo recuerdo» dice mientras recoge un libro de la mesilla. ${ }^{23}$ Esta especie gemela de cortinillas de entrada y

${ }^{23}$ Entre aquí y ahora, I remember alude al célebre poema de Joe Brainard en uno de cuyos versos leemos: «I remember (spooky) when all of a sudden someone you know very well becomes momentarily a total stranger». 
cierre responden a una voluntad clara de archivar en un espacio limitado la totalidad de la experiencia —entre los tres billones de años a.C. y el 22115 d.C.- - que contrasta claramente con el ideal utópico en favor de aquello que Foucault denominó heterotopia, un espacio de exclusión funcional a la norma social:

Vemos que el cementerio es un lugar heterotópico en grado sumo, ya que el cementerio se inicia con una rara heterocronía que es, para el individuo, la pérdida de la vida, y esta cuasi eternidad en la que no cesa de disolverse y eclipsarse. [...] En revancha, la idea de acumularlo todo, la idea de formar una especie de archivo, el propósito de encerrar en un lugar todos los tiempos, todas las épocas, todas las formas, todos los gustos, la idea de habilitar un lugar con todos los tiempos que está él mismo fuera de tiempo, y libre de su mordedura, el proyecto de organizar de este modo una especie de acumulación perpetua e indefinida del tiempo en un lugar inmóvil es propio de nuestra modernidad. El museo y la biblioteca son heterotopías propias de la cultura occidental del siglo XIX. ${ }^{24}$

\section{La cripta y el fantasma}

Aún en estado larvario, la tesis derridiana de la espectralidad comenzó a tomar forma a partir de 1959, año en que el filósofo francés trabaría amistad con la pareja de psicoanalistas compuesta por Nicolás Abraham y María Torok. El trabajo de ambos cristalizó casi dos décadas después a través de una reinterpretación del caso más perturbador de Freud, el hombre de los lobos, para la que Jacques Derrida escribiría su introducción Fors. En este y sucesivos libros, Abrahams y Torok propusieron una reorientación radical de las teorías freudianas allende el complejo de Edipo a través de dos nuevas nociones psicoanalíticas: la cripta y el fantasma.

Cuando sufrimos la pérdida de un ser querido, el dolor asociado al trauma suele elaborarse gradualmente a través de un proceso de duelo o introyección que, en casos extremos, se transforma en aflicción melancólica. No obstante, todas estas emociones no siempre pueden ser reconocidas y, en vez de asimilarlas, el sujeto las incorpora, las traga inmediata e instantáneamente para enterrarlas y preservarlas en un lugar extranjero dentro de sí mismo: la cripta. Esta cripta no afecta solamente al sujeto, sino que transmite a su descendencia por empatía con el inconsciente parental un secreto familiar reprimido entre generaciones - muertos enterrados en otros, estos son los fantasmas.

Finalmente, ambos conceptos, la cripta y el fantasma, se entrelazan en la obra de Abrahams y Torok para reconfigurar el psicoanálisis en una suerte de descodificación criptográfica del inconsciente, en sus propias palabras: «considerar el organismo como un texto jeroglífico, sedimentado a lo largo de la historia de la especie» o como resume Derrida:

Reencontrar el camino de la tumba, violar entonces una sepultura, he aquí aquello que se parece al análisis de una incorporación críptica. [...] Pero la sepultura violada no era ella misma legal. [...] Esta imagen misma, aquella del fantasma, habitante de una cripta propia del Yo [...] designa

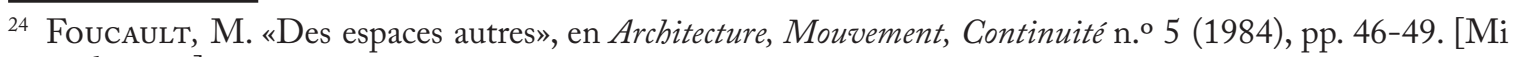
traducción]. 
también para el paciente, la ocasión del tormento, un recuerdo que él había enterrado sin sepultura legal $[\ldots]$, esperando su resurrección. ${ }^{25}$

En menos de diez años, uno de los discípulos de Abrahams y Torok, el psicoanalista francés Serge Tisseron, aplicaría este método criptográfico a una historieta - las aventuras de Tintín- con unos resultados llamativamente eficaces. ${ }^{26} \mathrm{~A}$ partir del simple estudio de los álbumes de Hergé, Tisseron fue capaz de desvelar un doloroso secreto que recorre tanto las peripecias del reportero belga como la historia familiar de su creador, una interpretación que posteriormente acreditarían diferentes documentos en varias biografías.$^{27} \mathrm{El}$ núcleo de este misterio se encuentra agazapado en el díptico formado por El secreto del Unicornio y El tesoro de Rackham el Rojo, cuyo motivo principal orbita alrededor de los orígenes familiares del Capitán Haddock.

Dentro del mástil roto de la maqueta de un barco recién adquirida, Tintín encuentra un trozo de pergamino con parte de unas coordenadas geográficas. Casualmente, el barco en que se basa la maqueta, el Unicornio, había pertenecido a un antepasado del Capitán Haddock, el caballero de Hadoque, quien robó un tesoro al pirata Rackham el Rojo para supuestamente enterrarlo en una isla tropical. Tintín, Haddock y Tornasol parten hacia esta isla en busca del trofeo, pero, una vez allí, no encuentran nada. Sin embargo, en un cofre dentro del Unicornio aparecen unos legajos identificando a Hadoque como propietario del castillo de Moulinsart que pasará a manos del Capitán Haddock. De vuelta en el castillo, oculto tras una estatua de su cripta, aparece el tesoro que nuestros amigos llevaban tanto tiempo persiguiendo.

En resumen, el tesoro se encuentra escondido en la cripta del castillo de Moulinsart, cedido en su momento por Luis XIV, el Rey Sol, a «nuestro querido y amado» François de Hadoque. Por tanto, la residencia legítima de Haddock oculta, como donativo real, un tesoro en su interior. ¿Por qué tomarse tantas molestias en enterrar las joyas de la familia? Un fantasma acecha a la genealogía del Capitán. ¿Qué vínculo une a su ancestro con una realeza que, oro y casa mediante, parece haber querido comprar su silencio? Apoyándose en las fechas aportadas por los álbumes, Tisseron propone que el caballero de Hadoque sería un hijo bastardo de Luis XIV. Esta hipótesis se confirmaría años después al revelarse que los gemelos Alexis y Léon, padre y tío de Hergé, eran aparentemente hijos ilegítimos o bien del conde Gaston de Errembault o bien del propio rey Leopoldo II de Bélgica. Quizás no sea anecdótico que Alexis, el padre, fuera contratado durante años como archivero, responsable de la memoria, de los Estudios Hergé.

«¿Cuál es la historia tras ese edificio del otro lado de la calle?», se pregunta una mujer con la vista puesta a través de la ventana de Here en 1984. El otro edificio es quizás el protagonista

${ }_{25}$ Derrida, J. «Fors», en Abrahams, N. y Torok, M. Le Verbier de l'homme aux loups. París, Flammarion, 1976, pp. 49-50.

26 Tisseron, S. Tintin no psicanalista. Lisboa, Bertrand Editora, 1987.

27 Smolderen, T. y Streckx, P. Hergé, Portrait biographique. Tournai, Casterman, 1988. 




FIG. 8. Pavlos Ky, M. E. Proprietary House. Perth Amboy, New Jersey, 2016.

secundario del cómic de Richard McGuire. Su historia, entre 1763 y 1777, se detalla en una frecuencia de hasta catorce viñetas a página completa, la mayor de todo el libro. Vemos cómo se tala el terreno, cómo se construye la mansión, cómo se celebra una cena en 1775 que acaba en una acalorada discusión política y cómo, posteriormente, la casa arde misteriosamente en llamas.

El edificio en cuestión, conocido como Proprietary House (FIG. 8), fue la residencia del gobernador colonial de New Jersey, nominalmente William Franklin, hijo de uno de los padres fundadores de Estados Unidos, Benjamin Franklin, quien la visita en compañía de su nieto William Temple Franklin. El motivo de la reyerta es evidente: Benjamin apoya el proceso de secesión norteamericano mientras su hijo se supedita a la corona británica, tachándolo de «terrorista».

Sin embargo, bajo la querella de emancipación política yace un fantasma familiar que unos niños se encargan de señalar: «ßBastardo!». William es un hijo ilegítimo de Benjamin que, a su vez, hizo heredar esta condición a William Temple, un sucio secreto entre generaciones. Como no podía ser de otra manera, esta mansión arrastra su propia leyenda de haunted 
bouse, casa encantada, sometida al asedio de diversos fantasmas, incluyendo un soldado de la Guerra de Independencia, una mujer vestida de blanco y un niño.

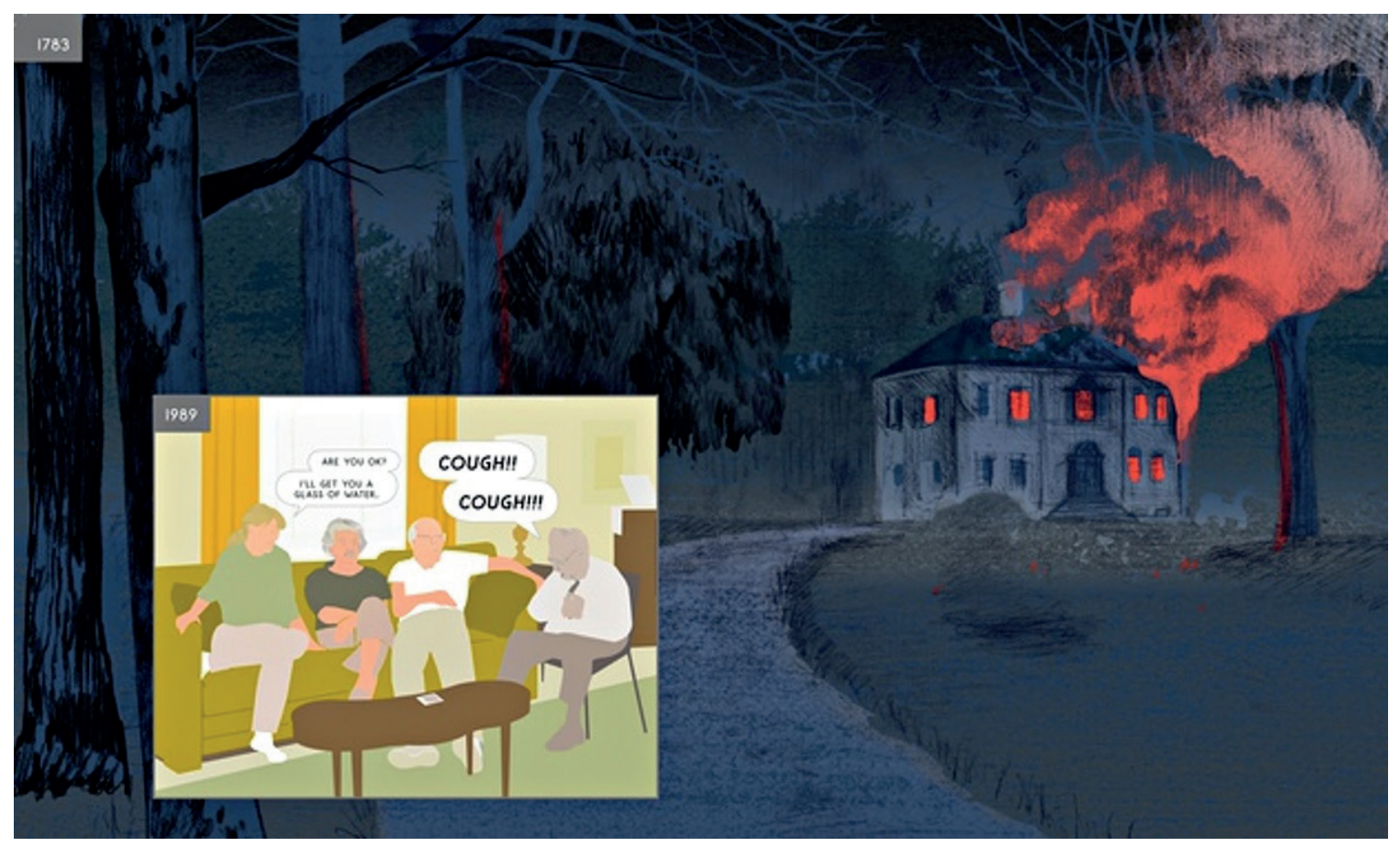

FIG. 9. McGuire, R. (2014) Op. cit. pp. 25-26.

Una doble página clave (FIG. 9) presenta el incendio de la Proprietary House en 1783 cuyo humo parece incorporarse a los pulmones del tío de Richard McGuire quien, en 1989, intenta expulsarlo tosiendo mientras se cae de una silla tras contar un chiste y muere súbitamente de un ataque al corazón. Las complejas relaciones de superposición entre viñetas se renuevan así en términos de incorporación y/o exteriorización sincronizando dos criptas, dos casas, atravesando dos planos temporales, dos épocas históricas mediante un fenómeno espectral que descodifique el jeroglífico intergeneracional de Here.

\section{La casa y el conjurado}

La teoría derridiana de la espectralidad tomaría cuerpo definitivo con su libro Espectros de Marx publicado en 1993. Al poco de caer el muro de Berlín, Derrida se mide con el patriarca de buena parte de la izquierda política a partir de la frase con que se abre el Manifiesto comunista — «un espectro asedia Europa, el espectro del comunismo»-, repasando las apariciones de esta figura en la obra de Marx desde la repetición de la historia como farsa en El $18 \mathrm{Bru}$ mario de Luis Bonaparte hasta el carácter espectral del valor en La ideología alemana y El capital.

Con todo, Espectros de Marx debe situarse en relación con el conjunto de su filosofía de la diferencia, es decir, también de lo diferido, frente a la metafísica de la presencia, es decir, 
también del presente, porque Espectros de Marx es, sobre todo y entre otras cosas, un libro intempestivo, con pretensión de impugnar el tiempo histórico en su desarrollo lineal teleológico característico de las promesas políticas que protagonizaron la era moderna.

Así, Derrida piensa el espectro como anacronía radical, figura de la no contemporaneidad consigo mismo del tiempo presente, apoyándose en la célebre frase de Hamlet: «The time is out of Joint, el tiempo está desarticulado, descoyuntado, desencajado, dislocado, el tiempo está trastocado, acosado y trastornado, desquiciado, a la vez desarreglado y loco». ${ }^{28}$

Esta problemática coexistencia espectral entre diferentes capas temporales es recuperada por Derrida, por ejemplo, a través de El 18 Brumario de Luis Bonaparte —obra sobre el placaje de la revolución de 1848 que funda el materialismo histórico- cuyo motivo de la repetición como farsa Marx atribuye, de buen principio, a Luis Felipe de Orleans en tanto sombra patética de su abuelo Napoleón.

En estas épocas de crisis revolucionaria es precisamente cuando [los hombres] conjuran temerosos, en su auxilio los espíritus del pasado toman prestados sus nombres, sus consignas de guerra, su ropaje, para, con este disfraz de vejez venerable y este lenguaje prestado, representar la nueva escena de la historia universal. Así, Lutero se disfrazó de apóstol Pablo, [...] los partidos y la masa de la antigua revolución francesa, cumplieron, bajo el ropaje romano y con frases romanas, la misión de su tiempo [...] Cromwell y el pueblo inglés habían ido a buscar en el Antiguo Testamento el lenguaje, las pasiones y las ilusiones para su revolución burguesa. [...] Una vez instaurada la nueva formación social, desaparecieron los colosos antediluvianos, y con ellos el romanismo resucitado. ${ }^{29}$

Estas escenas en que el pasado es repetido como parodia, en forma de disfraz, abundan en Here: una fiesta de Halloween - el día de los muertos, de las casas encantadas- donde alguien aparece vestido de Benjamin Franklin; el árbol de Navidad, un disfraz espectral de su anterior vida vegetativa; la escena de una casa de muñecas que replica y pone en abismo la misma habitación. Pero, sobre todo, destacan las vinculadas a la anteriormente oriunda tribu de los Lenape: un niño trajeado de indio ante su tipi, la historia sobre el monstruo del bosque que parece ser otro niño disfrazado de oso en la misma doble página, la cabeza de ciervo decorativa como trofeo de su caza pretérita. ¿Por qué estos personajes conjuran en su ayuda a los espectros del pasado? Para dimensionar, y así digerir, el trauma histórico que conllevan: el exterminio de los nativos, la guerra de independencia...

${ }^{28}$ Derrida, J. (2012). Op. cit., p. 31.

${ }^{29}$ Marx, K. El 18 Brumario de Luis Bonaparte. Buenos Aires, Anteo, 1972, pp. 15-17. Finalmente concluye, p. 162: «La tradición histórica hizo surgir en los campesinos franceses la fe milagrosa de que un hombre llamado Napoleón les devolvería su esplendor. Y se encontró un individuo que se hace pasar por tal hombre porque luce el nombre de Napoleón y como consecuencia del Code Napoleon, que prescribe: Toute recherche de la parternité est interdite [Toda investigación de la paternidad queda prohibida]». En clave psicoanalítica, Spivak interpreta esta última cita: «La ausencia del nombre propio colectivo, artificial y no familiar, es suplida por el único nombre propio que la tradición bistórica puede ofrecer —el patronímico mismo- el Nombre del Padre [...]. Es la Ley del Padre —el Código napoleónico- la que paradójicamente prohíbe la búsqueda del padre natural». SpivaK, G. C. «¿Puede hablar el subalterno?», en Revista Colombiana de Antropología, vol. 13 (2003), p. 313. 
Dentro del tiempo estratigráfico de Here podrían distinguirse, por ejemplo, cuatro planos: el plano cuasi-geológico de los amaneceres, el plano biológico de los animales y las plantas, el plano sociohistórico de los grandes acontecimientos y, al fin, el plano de la vida cotidiana, tanto del lugar como de sus eventuales habitantes. En este último destaca, por su carácter alegórico, la secuencia donde una sociedad arqueológica visita la casa de los McGuire - momento que sucedió efectivamente- uno de cuyos miembros porta una camiseta con el irónico lema de «Future transitional fossil». Sin duda, no es posible aplicar una jerarquía entre las diferentes capas fosilizadas o por fosilizar: hay fósiles directores - restos paleontológicos o arqueológicos que permiten datar ciertos planos- pero no hay aquí ningún archifósil primordial que permita probar la preexistencia de la realidad antes del observador, ${ }^{30}$ sino un solo plano de inmanencia, en palabras de McGuire: «quería relatar los pequeños momentos de la vida, dándole a las pequeñas cosas la dignidad de los grandes eventos y, viceversa, restituir a las cosas grandes la dimensión de la cotidianeidad». ${ }^{31}$

Este plano inmanente sin jerarquías aspira a abarcar la totalidad de la experiencia - ya lo habíamos visto - pero, en la era Wikipedia, totalidad no significa clausura. Como podemos observar en las notas preliminares de Here (FIG. 10), McGuire intenta —al modo de una partitura o poesía - articular el tiempo a partir del ritmo, de la repetición; acoplar los momentos en tanto diferentes notas musicales, o letras, que atrapen la totalidad temporal a partir de un número virtualmente finito de vistas, actualizadas o no en una melodía o en otra harmonía. Una apertura que Groensteen aplica a la datación de las viñetas:

El carácter a menudo fluido, incierto, aproximativo, brumoso de la rememoración [...] se contra-
dice aquí con una precisión que puede parecer obsesiva y maniaca. La datación produce el efecto
de instalar rápidamente esa sensación de extravío, ya que ella indica de manera clara que las imá-
genes descubiertas sucesivamente no son consecutivas; pero también permite adelantarse, dando
la impresión de que el libro incluye sus «instrucciones de uso», suscitando casi inevitablemente
en el lector la tentación de reensamblar el puzzle temporal, de darle una forma más inteligible.
Perspectiva ilusoria, naturalmente [...] La datación permite al menos circular por el libro, hacia
delante y hacia atrás, para activar los solapamientos, verificar como las líneas del relato se consti-
tuyen, se cruzan, encontrando o no una resolución.

Sin embargo, Here, aquí, es un lugar concreto: el número 150 de la Avenida Kearny en Perth Amboy (New Jersey), vendido en octubre de 2012 tras haber sido el hogar de los padres de Richard McGuire durante cincuenta años. Inicialmente, el autor se resistió a utilizar la casa como escenario del libro ya que le obligaba a enfrentarse al duelo por la reciente muerte de ambos junto a su hermana. Superado el anclaje en la negación, el mismo volumen —dedicado a su familia - formaría parte de este proceso de duelo, cuyas fases se reflejan de manera flexible en su estructura central: a la caída mortal del comienzo le sigue una fase de negociación

30 Meillassoux, Q. Después de la finitud: Ensayo sobre la necesidad de la contingencia. Buenos Aires, Caja Negra Editora, 2015, pp. 23-51.

31 Pansini, A. «Richard McGuire sulla genesi e le tematiche presenti en Qui». en Lo Spacio Bianco (31 de mayo de 2015). Disponible en http://www.lospaziobianco.it/richard-mcguire-genesi-tematiche-presenti/.

32 Groensteen, T. (2016). Op. cit. [Mi traducción]. 


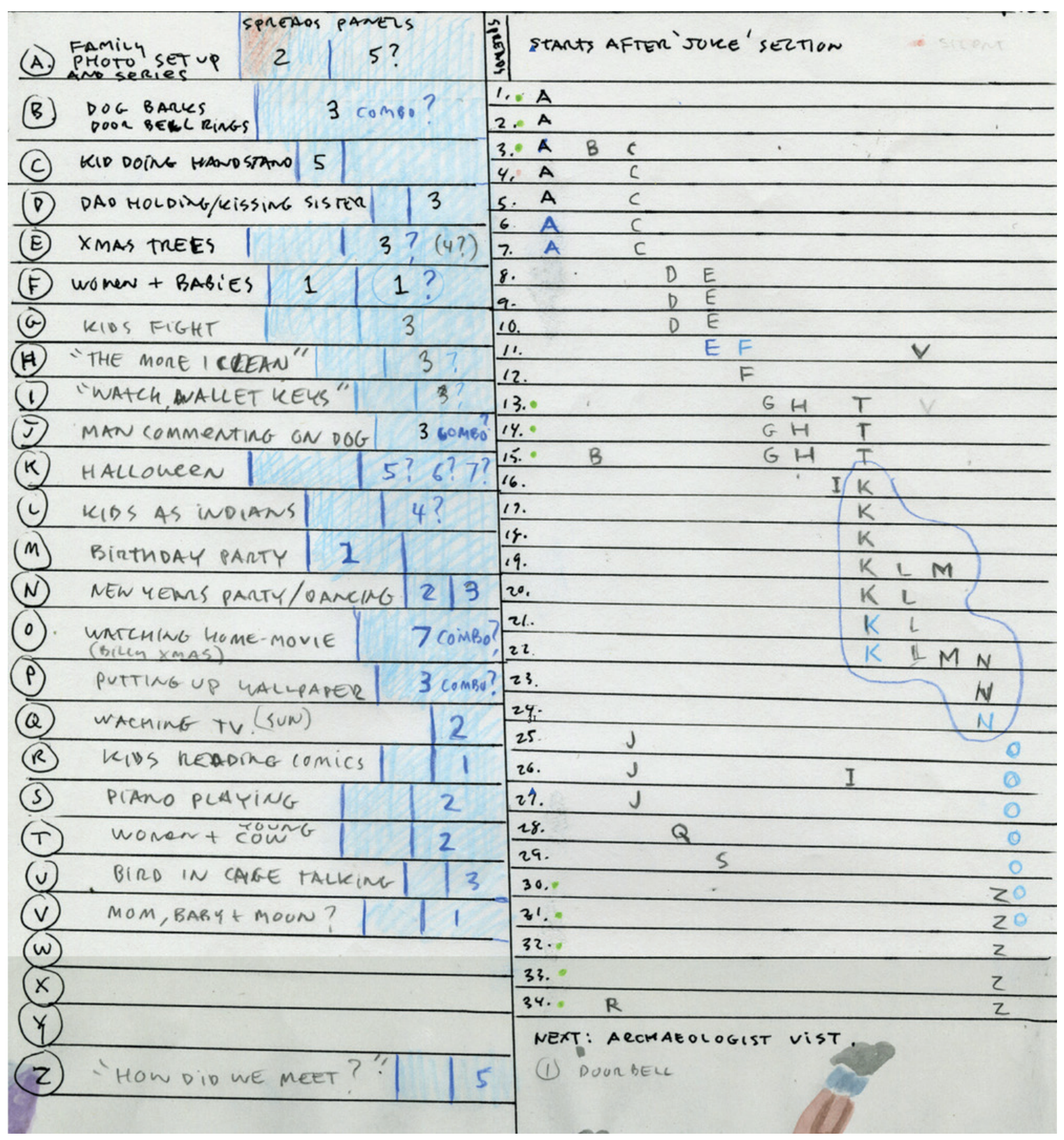

FIG.10.McGuire, R. «Richard McGuire Makes a Book» en Five Dials n. 35 (2015), pp. 31-32.

entre la familia Franklin que desemboca en un clímax iracundo de imágenes sobre peleas e insultos y continúa con una serie de páginas sobre el motivo de la pérdida para, finalmente, presentar la secuencia melancólica de los amaneceres, entre la aceptación y la depresión. Este, el trabajo del duelo, es el verdadero núcleo y tema central de Here.

El conjurado tiene que ver, por tanto, con el trabajo del duelo, con una mirada retrospectiva que convoca a los espectros, pero, también, de futuro en tanto la conjura implica en Here 
un juramento, una promesa, un compromiso entre el plano sociohistórico y el cotidiano proyectándose hacia el porvenir, «una política de la memoria, de la herencia y de las generaciones». ${ }^{33}$

De vuelta a Marx y Derrida, definamos un terreno común: la economía, de la casa o de la habitación, la ô̂kos, esta es la ley, nómos, procedente de némō, pastorear, es decir, distribuir los pastos entre los nómadas — recordemos el Ars Memoriae y el mapa temporal como escritura cardinal de estos pueblos- Con todo, a través de los teólogos cristianos, la oikonomía adquiriría un nuevo sentido vinculado a la revelación de la Santísima Trinidad que distingue en sí al Padre, al Hijo y al Espíritu, tal como hoy discernimos tres formas diferentes del capital: industrial, comercial y financiero. ${ }^{34}$

En este punto, el desencuentro entre Marx y Derrida es evidente: mientras en la doctrina marxista se discute todavía sobre si el «valor espectral» de la mercancía surge en la producción o en la circulación de la economía capitalista, ${ }^{35}$ la deconstrucción orienta su mirada hacia la economía general del don, intentando substraerlo a un no-lugar fuera del circuito económico, tanto del intercambio como de la deuda. ${ }^{36}$

Desde este ángulo, la economía espectral debe inclinarse claramente por esta última (des) encarnación especulativa, por la relaciones entre el crédito y la deuda, algo que ya sabíamos a partir de cualquier relato sobre el asedio de los fantasmas, pero que se concretaría ante nuestros ojos brutalmente en 2008 con la crisis de crédito hipotecario - del griego bypothéke, literalmente «bajo el sepulcro» o, en inglés, mortgage, «compromiso de muerte»— tras la que se vendería la casa familiar de los McGuire.

En este sentido, la singular elección del término espectralidad como núcleo de la interpretación derridiana de la obra de Marx contrasta con la tesis tradicional que parte de su crítica al «fetichismo de la mercancía». Las relaciones marxianas entre la mercancía-fetiche y el valor-espectro destituirían así, renovando, los polos de la dualidad hegeliana entre cuerpo

33 Derrida, J. (2012). Op. cit., p. 12. El filósofo francés señala que el significado de conjuración, además de conspiración, bascula entre evocar y exorcizar, dar entrada y salida al espectro, v. Ibid., pp. 53-62.

34 Agamben, G. El reino y la gloria. Valencia, Pre-textos, 2008.

35 En línea con Althusser, la Neue Marx-Lektüre de Michael Hendrich rechaza la teoría substancialista del valor-trabajo - de acuerdo con la cual la esencia del valor es un producto directo del tiempo de trabajoen favor de la tesis de que la «objetividad espectral» del valor se constituye dentro de las relaciones de intercambio sin que esto signifique la preexistencia de un reino ontológico de las cosas en sí, v. HeINRICH, M. Crítica de la economía política: una introducción a El Capital de Marx. Madrid, Escolar y Mayo, 2008, pp. 57-91. Sobre Marx y la deuda v. Lazzarato, M. La fábrica del hombre endeudado. Buenos Aires, Amorrortu, 2013, pp. 61-74.

36 Derrida, J. Dar (el) tiempo I: la falsa moneda. Barcelona, Paidós, 1995, p. 22: «Para que haya don, es preciso que el donatario no devuelva, ni amortice, ni salde su deuda, ni la liquide, es preciso que no se meta en ningún contrato, ni haya contraído jamás ninguna deuda [...] Es preciso, en último extremo, que no reconozca el don como don. Si lo reconoce como don, si el don se le aparece como tal, si el presente le resulta presente como presente, este simple reconocimiento basta para anular el don». 
y espíritu o cosa y persona. ${ }^{37}$ Obviamente, la tesis deconstructivista postula la indistinción de ambos, pero desplaza sutilmente su atención a la «objetividad espectral» en detrimento del fetiche. ${ }^{38}$

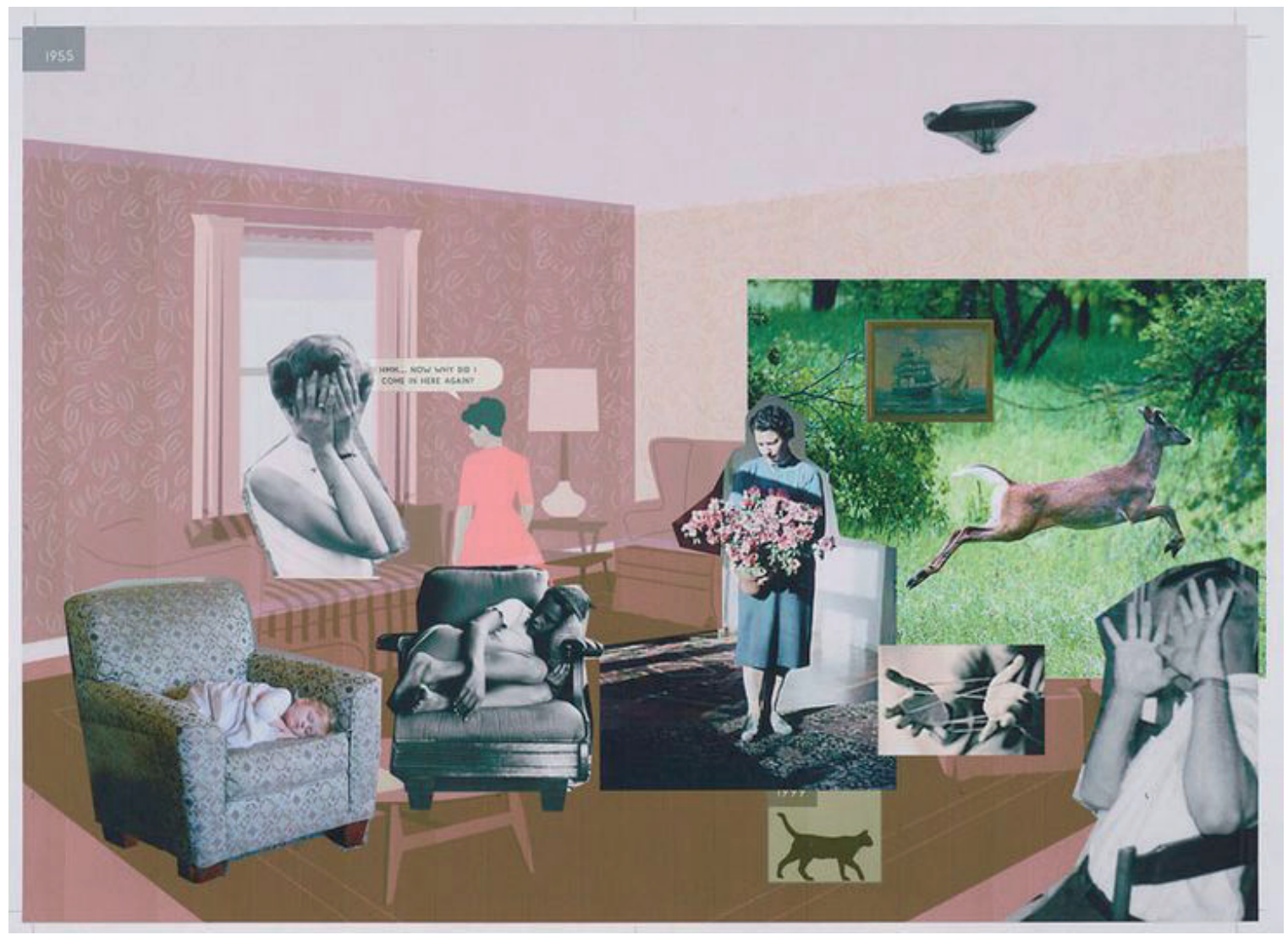

FIG. 11. McGuire, R. «Boceto digital a doble página de Here», en The Morgan Library $\&$ $M u-$ seum, 2014.

En el proceso digital previo a la realización de Here, McGuire utilizó una técnica que, de por sí, ya identifica históricamente al arte de vanguardia: el collage (FIG. 11). ${ }^{39}$ Con inde-

37 Esposito, R. Dos: La máquina de la teología politica y el lugar del pensamiento. Buenos Aires, Amorrortu, 2015, pp. 161-169. De raíz Hegeliana, la categoría de fetiche fue apuntalada por Lukács, contraponiendo su cosificación al humanismo. Lukács, G. Historia y Conciencia de clase. La Habana, Instituto del libro, 1970, pp. 110136. Para una interpretación del fetiche posmoderna y fuera de la órbita marxista v. Latour, B. On the Modern Cult of the Factish God. Durham, Duke University, 2010, donde vincula el término fetiche que deriva del portugués feitiço, equivale al castellano «hechizo» y proviene del latín factitius (artificial) con el español hecho, francés fait o inglés fact, entendido hoy como realidad frente a su significado original próximo a producto.

38 Derrida, J. (2012). Op. cit., p. 144. «El fetiche sería el cuerpo dado o, mejor, prestado, de prestado, la encarnación secundaria conferida a una idealización inicial.» [Mis cursivas]. Obviamente, para Marx el fetiche definitivo es la moneda,

${ }^{39}$ La muestra Richard McGuire-Ici celebrada entre febrero y abril de 2015 en la Galerie Martel de París, indica la diversidad de materiales que utilizó en la realización de su cómic: desde el acrílico sobre madera 
pendencia de que este surgiera a través del movimiento cubista - tan preocupado por el cuestionamiento de la percepción y representación del espacio- e incluso de que existan antecedentes de narrativa visual como Una semana de bondad, de Max Ernst, la referencia inexcusable de Here es la obra de Richard Hamilton Just what is it that makes today's homes so different, so appealing?, que sirvió como póster, en 1956, de la exposición This Is Tomorrow, y es considerado generalmente como el cuadro fundacional del Pop Art (FIG. 12).

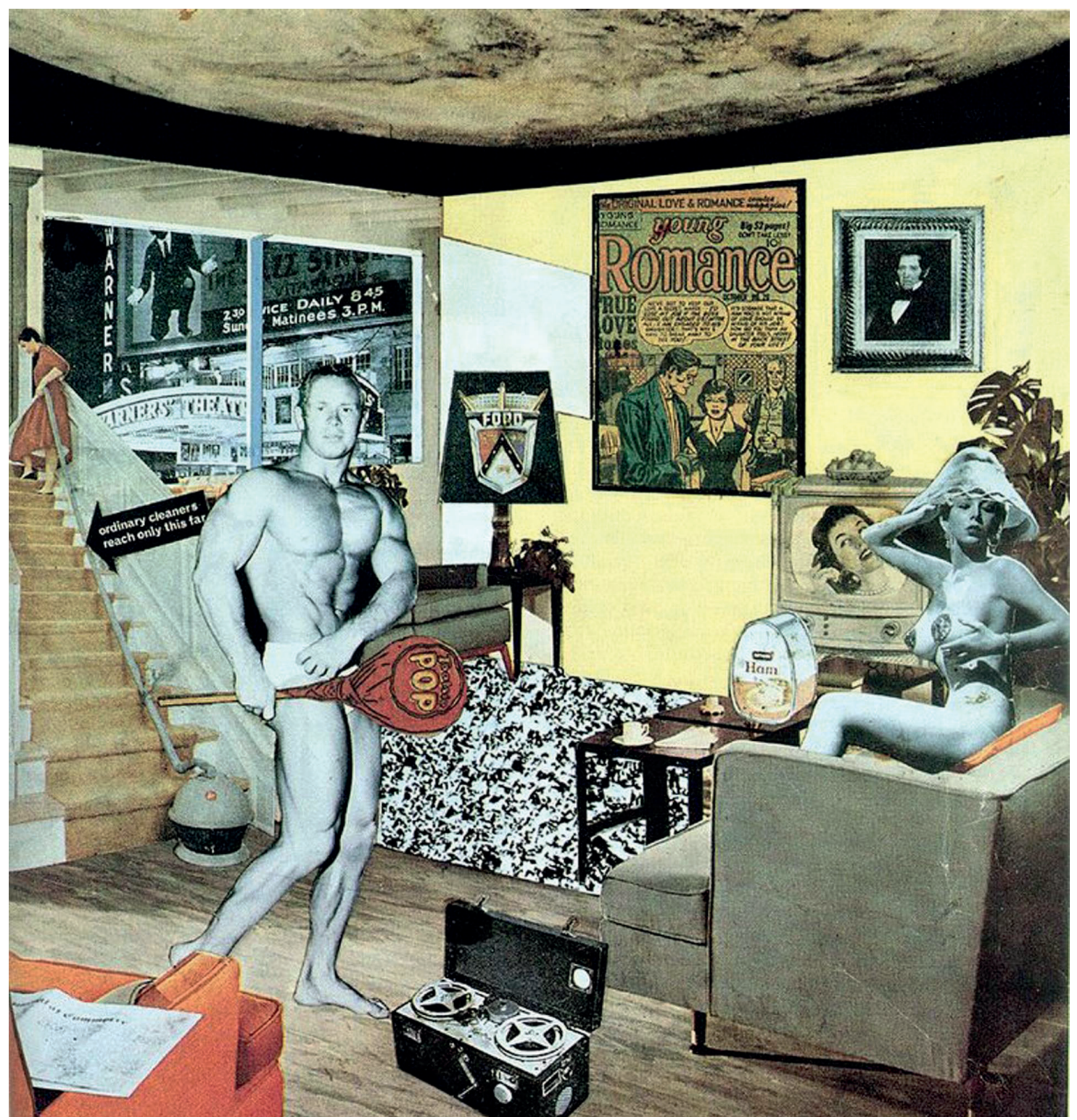

FIG. 12. Hamilton, R. 1956, Just what is it that makes today's homes so different, so appealing?

hasta las témperas y acuarelas sobre papel. Disponible en http://www.lospaziobianco.it/richard-mcguire-genesi-tematiche-presenti/. 
El catálogo de la exhibición describe este collage de la siguiente manera: «El hombre, la mujer, la humanidad, la historia, la comida, los periódicos, el cine, la televisión, el teléfono, los cómics (información visual), las palabras (información textual), los registros magnetofónicos (información auditiva), los coches, los electrodomésticos, el espacio». ${ }^{40}$ Entre las imágenes tomadas de diversas revistas para formarlo, tres remiten directamente a Here: la disposición de la sala de estar estructurada a partir de su quicio como falso punto de fuga con la ventana en la misma posición, la publicidad de la aspiradora Hoover para el «ama de casa» y, por supuesto, el cuadro con una portada del tebeo romántico Young Romance, de Joe Simon y Jack Kirby.

El collage de Hamilton se presta con facilidad a una lectura superficial desde el «fetichismo de la mercancía»: un hogar repleto de productos de consumo cuyos atributos parecen extenderse hasta la mujer que levanta sus senos o el hombre que sujeta un lollipop; pin-up o vigoréxico que hacen de su cuerpo un motivo de exhibición en el circuito libidinal. De igual manera, la técnica del collage también se presta a una lectura espectral en tanto transferencia, puesta en valor y archivo de imágenes-souvenirs desde el ámbito profano de los medios de comunicación o la vida cotidiana al ámbito institucional del arte o la literatura, según el procedimiento del readymade. ${ }^{41}$

El fetiche concentra imágenes mientras el espectro las transfiere y así podrían identificarse, respectivamente, con los dos mecanismos de defensa inconsciente que Freud detectó en su interpretación de los sueños: la condensación y el desplazamiento.

\begin{abstract}
En realidad, la memoria es el antimuseo: no es localizable. [...] Allí duerme un pasado, como en las acciones cotidianas [...] donde sueñan antiguas revoluciones [...] No habitamos sino lugares encantados [...] Los lugares son historias fragmentadas y replegadas, pasados robados a la legibilidad por los otros, tiempos amontonados que pueden desplegarse pero que están allí más bien como relatos a la espera y que permanecen en estado de jeroglífico [...] Lo memorable es lo que puede ser soñado acerca del lugar. Una vez en este lugar palimpsesto, la subjetividad se articula sobre la ausencia que la estructura como existencia. ${ }^{42}$
\end{abstract}

Igualmente, presentes en Here, estos fenómenos nos entregan al misterio de una fábula onírica, en último término indiscernible incluso para su propio autor pero vinculada a una economía, a su ley y a su casa, como apunta Boris Groys: «El don de la indiscernibilidad tampoco se escapa a la economía general del don, pues la indiscernibilidad también puede

40 Texto del catálogo de la exposición This Is Tomorrow, cit. en Foster, H. The First Pop Age. New Jersey, Princeton University Press, 2012, pp. 22-23. Para esta obra, Hamilton colaboró intensamente con los arquitectos John Voelcker y Reynerd Banham.

${ }^{41}$ Duchamp, precursor para Richard Hamilton, crearía en 1917 su célebre primer readymade u objet trouvé, «La fuente»: un urinario volcado, directamente así trasladado para su exhibición y firmado como R. Mutt. Thomas Inge aventura la hipótesis de que esta signatura fuese un homenaje a la tira de prensa Mutt and Jeff de Bud Fisher. Inge, T. Comics as Culture. Jackson, University Press of Mississippi, 1990, pp. 42-43.

42 Certeau, M. L'invention du quotidien, vol. 1. París, Gallimard, 2012, pp. 159-163. [Mi traducción]. 
regalarse y aceptarse: el procedimiento del readymade no es otra cosa que el regalo de esa indiscernibilidad». ${ }^{43}$

Here prácticamente se cierra con la tonadilla popular que cantan unos niños: «Ring-a-round the rosiel A pocket full of posies/ Ashes! Ashes!/ We all fall down» y Derrida concluye, refiriéndose a Freud como bien podría haberlo hecho sobre Richard McGuire:

El secreto es la ceniza misma del archivo [... Nos preguntaremos lo que ha podido guardar de su derecho incondicional al secreto, ardiendo en deseos de saber [...] Siempre nos preguntaremos lo que él ha podido quemar, en ese mal de archivo. Siempre nos preguntaremos, compartiendo con compasión ese mal de archivo, lo que ha podido arder de sus pasiones secretas, de su correspondencia o de su «vida». ${ }^{44}$

Dedicado a Vicente Luís Mora

${ }^{43}$ Groys. Op. cit., p. 230.

${ }^{44}$ Derrida, J. (1997) Op. cit., pp. 106-107. 


\section{Bibliografía}

Agamben, G. El reino y la gloria. Valencia, Pre-textos, 2008.

Anónimo. Retórica a Herenio. Madrid, Gredos, 1997.

Cicerón, M. T. Sobre el Orador. Madrid, Gredos, 2002.

Corn, N. Visual Syntactic Structures: Towards a Generative Grammar of Visual Language. 2003. Disponible en http://visuallanguagelab.com/P/VSS1.pdf

Crary, J. Las técnicas del observador: visión y modernidad en el siglo XIX. Murcia, CENDEAC, 2008.

De Certeau, M. L'invention du quotidien, vol. 1. París, Gallimard, 2012.

De Moura, P. «Time is a Memory, Liquid is a Cup», en Du9: l'autre bande dessinée, 2015. Disponible en http://www.du9.org/en/dossier/time-is-a-liquid-memory-is-a-cup/

Derrida, J. «Fors», en Abrahams, N. y Torok, M. Le Verbier de l'homme aux loups. París, Flammarion, 1976.

- Dar (el) tiempo I: la falsa moneda. Barcelona, Paidós, 1995.

- Mal de archivo. Madrid, Trotta, 1997.

- Espectros de Marx: el Estado de la deuda, el trabajo del duelo y la nueva Internacional. Madrid, Trotta, 2012.

Esposito, R. Dos: La máquina de la teología política y el lugar del pensamiento. Buenos Aires, Amorrortu, 2015.

Fisher, M. Ghosts of My Life: Writings on Depression, Hauntology and Lost Futures. Alresford, Zero Books, 2014.

Foster, H. The First Pop Age. New Jersey, Princeton University Press, 2012.

Foucault, M. «Des espaces autres», en Architecture, Mouvement, Continuité n. 5 (1984), pp. 46-49.

Groensteen,T.«Les lieux superposés de Richard McGuire»,en Urgences n. 32 (1991),pp. 95-103. Disponible en http://www.erudit.org/fr/revues/urces/1991-n32-urces651/025651ar.pdf

- Système de la Bande Desinée. París, Presses Universitaires de France, 1999.

— «Richard McGuire: Ici», en Musée de la Bande Dessinée (Angulema, marzo de 2016). Disponible en https://www.editionsdelan2.com/groensteen/spip.php?article60 
Groys, B. Bajo sospecha: una fenomenología de los medios. Valencia, Pre-textos, 2008.

Harguindey Barrio, B. «The Order of Comics: Dynamics of Ninth's Art Devices», en Cañero, J. y Claudio, E. (eds.). On the Edge of the Panel: Essays on Comics Criticism. Newcastle upon Tyne, Cambridge Scholars Publishing, 2015, pp. 65-73.

Heinrich, M. Crítica de la economía politica: una introducción a E1 Capital de Marx. Madrid, Escolar y Mayo, 2008.

Hockney, D. El conocimiento secreto. Barcelona, Destino, 2001.

Inge, T. Comics as Culture. Jackson, University Press of Mississippi, 1990.

Jameson, F. Las semillas del tiempo. Madrid, Trotta, 2000.

Konstantinuo, Lee. «A Theory of Here», en The Account, n. ${ }^{\circ} 4$ (2015). Disponible en http://theaccountmagazine.com/?article $=\mathrm{a}$-theory-of-here.

Latour, B. On the Modern Cult of the Factish Gods. Durham, Duke University, 2010, pp. 1-66.

Lazzarato, M. La fábrica del hombre endeudado. Buenos Aires, Amorrortu, 2013.

Locke, J. Ensayo sobre el entendimiento bumano. Lib. II, Cap. XI, 17. Londres, Thomas Teck, 1825. Disponible en https://archive.org/stream/humanunderstandi00lockuoft\#page/n117/mode/2up.

LukÁcs, G. Historia y conciencia de clase. La Habana, Instituto del libro, 1970 [1923].

Marx, K. El 18 Brumario de Luis Bonaparte. Buenos Aires, Anteo, 1972 [1852].

Marx, K. y Engels, F. La ideología alemana. Barcelona, Ediciones Grijalbo, 1974 [1846].

Masick, T.y Trainor, B. Here. [Video]. Nueva York, Rochester Institute of Technology, 1991. Disponible en https://www.youtube.com/watch?v $=57 \mathrm{hR} 44 \mathrm{mB} 5 \mathrm{u} 0$.

Meillansoux, Q. «Spectral Dilemma», en Collapse, vol. 5 (2008).

- Después de la finitud: Ensayo sobre la necesidad de la contingencia. Buenos Aires, Caja Negra Editora, 2015.

McGuire, R. «Here», en $R A W$, vol. 2, n. o 1 (1989), pp. 69-74.

— «Here», en Strapazin n. 59 (2000).

- Here. Londres, Hamish Hamilton, 2014. 
— «Richard McGuire Makes a Book», en Five Dials, n. 35 (2015). Disponible en http://fivedials.com/number-35-richard-mcguire-makes-a-book/.

Nietzsche, F. Aurora. Barcelona, Alba Editorial, 1999 [1881].

Pansini, A. «Richard McGuire sulla genesi e le tematiche presenti en Qui», en Lo Spacio Bianco (31 de mayo de 2015). Disponible en http://www.lospaziobianco.it/richard-mcguire-genesi-tematiche-presenti/.

Reynolds, S. Retromania. Buenos Aires, Caja Negra, 2012.

Ricoeur, P. Freud: una interpretación de la cultura. México, Siglo XXI, 1990.

RüEGG, N. SPUK. Zurich, Edition Fink, 2004.

Smolderen, T. y Streckxt, P. Hergé, Portrait biographique. Tournai, Casterman, 1988.

Spivak, G. C. «Puede hablar el subalterno?», en Revista Colombiana de Antropología, vol. 13 (2003) [1987], pp. 295-364.

Sprinker, M. (ed.) Ghostly Demarcations: A Symposium on Jacques Derrida's Specters of Marx. Londres, Verso, 1999.

Tisseron, S. Tintin no psicanalista. Lisboa, Bertrand Editora, 1987.

Ware, C. «Building Stories», en Acme Novelty Library, n. ${ }^{\circ} 16$ (2012).

Weitzman, K. El rollo y el códice: un estudio del origen y el método de la iluminación de textos. Donostia, Nerea, 1990. 